Department of Anatomy,

Faculty of Medicine, Assiut University.

\title{
EFFECT OF MONOSODIUM GLUTAMATE ON THE POST-NATAL DEVELOPMENT OF THE RETINA OF ALBINO RAT
}

(With 2 Tables and 30 Figures)

By

M.M. SALEH; A.H. ABD-ELHAKIM; HODA A. MOHAMAD
and HALA ZEIN EL-ABDEIN MOHAMED

(Received at 29/9/2005)

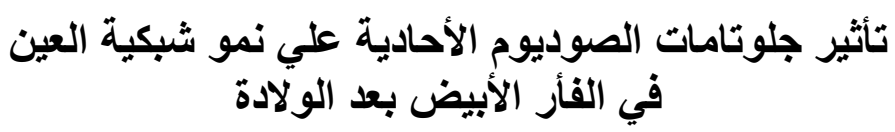

محه نبيل محمود صالح ، أشرف حمودة عبد الحكيم ، هلى أحد محه ، هالتة زبين العابلبين عمدة عهي

تتكون شبكية العين من عشرة طبقات ميكروسكوبية تشتمل في داخلها على سلسلة من الخلايا

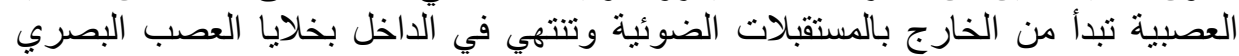

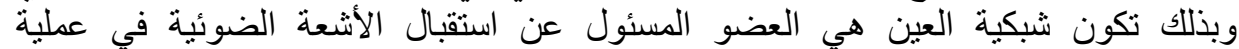

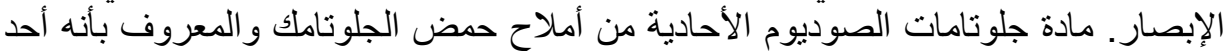

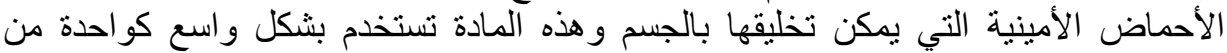

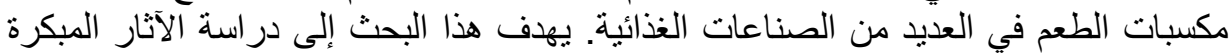

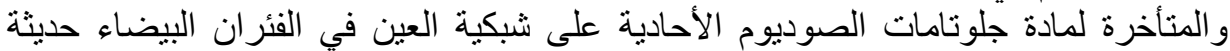

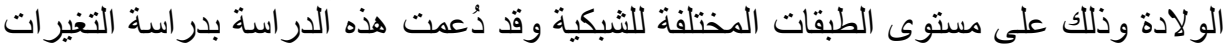

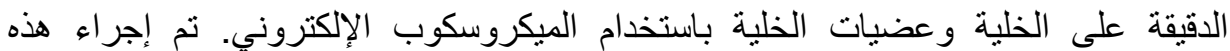

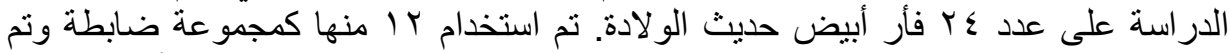

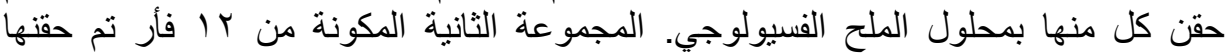

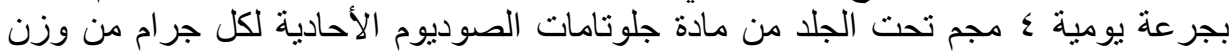

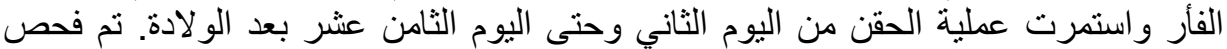

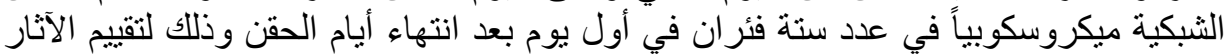

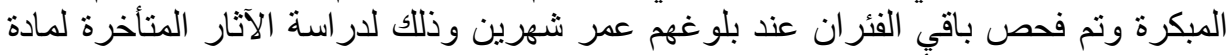

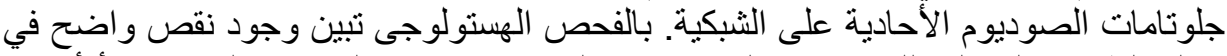

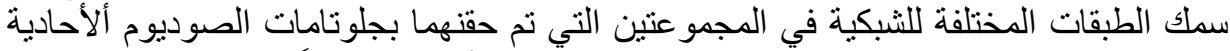

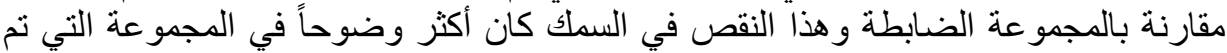

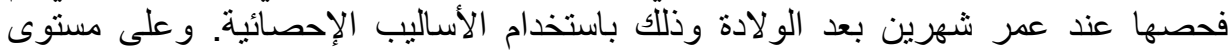

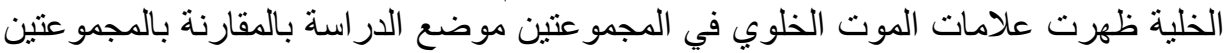

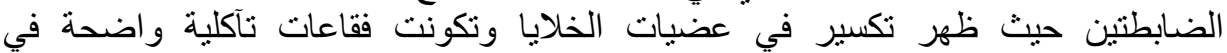




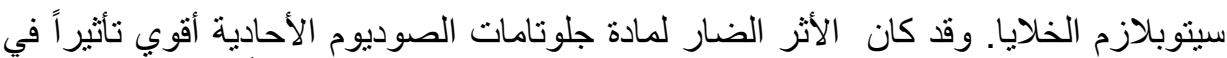

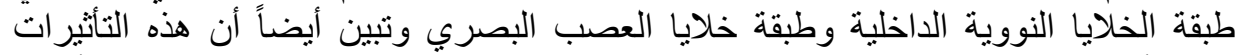

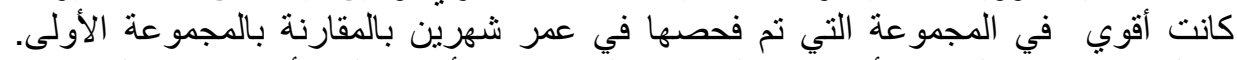

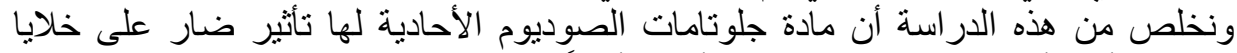

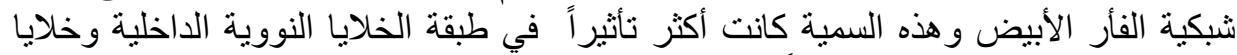

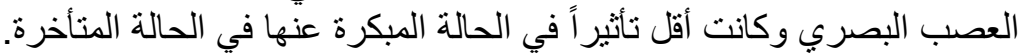

\section{SUMMARY}

The retina is the photoreceptor organ and is divided into ten layers which contain the neuronal elements (photoreceptor, bipolar, and ganglion cells). Monosodium glutamate is a widely used food additive as it enters in the preparation of many food types. It is the salt of glutamic acid, which is a non essential amino acid that can be synthesized in the human tissue. The aim of the present work is to detect the early and delayed effects of monosodium glutamate on the retina of neonatal albino rats by using histological and ultra structural techniques. A total number of 24 animals aged 2 days postnatal were used in this study. Twelve animals were used as controls and injected with saline. The other 12 animals were treated subcutaneously with $4 \mathrm{mg} / \mathrm{gm}$ body weight monosodium glutamate from the $2^{\text {nd }}$ to the $18^{\text {th }}$ day postnatal. The retina of six treated animals was examined in the next day after the last dose of treatment to detect the early effect of monosodium glutamate administration. The retina of the remaining six of the treated animals was examined later on at the age of 2 months to detect the delayed effect of monosodium glutamate. The semi-thin sections showed significant reduction in the thickness of different layers of the retina of the treated groups as compared with the control. This reduction was more marked in the treated 2 months age group as compared with the treated 19 days age group. This reduction in the thickness was detected by using statistical analysis using student t-test. On the ultra structural level manifestation of degeneration and cell death are observed in the treated groups. These include distortion in the shapes and dimensions of the cells and nuclei, marked vacuolization of the cytoplasm and destruction of the cell organelles. These monosodium glutamate induced ultra structural changes were prominent in the inner nuclear layer as well as in the ganglionic cell layer. Also these changes were more obvious in the older animals. It is concluded that monosodium glutamate has a toxic effect on different layers of the retina. This effect was more marked in the inner 
nuclear and ganglionic cell layers. In addition the late effect was more marked than the early effect.

Key words: Retina, monosodium glutamate, Rat.

\section{INTRODUCTION}

Glutamate is the most common neurotransmitter in the central nervous system. It plays a pivotal role in the formation of synapses and neuronal circuitry (Pelligrini-Giampetro, et al., 1997). Glutamate induces neuronal death by increasing the influx of $\mathrm{Ca}^{2+}$ through the selective glutamate receptor channels. $\mathrm{Ca}^{2+}$ triggers a cascade of reactions including free radical generation, lipid per-oxidation and activation of enzymes and apoptotic programs. Finally these reactions will destroy the cell (Nicholls \& Budd, 1998).

The adult mammalian retina is made up of ten well defined layers. These layers from outside inwards are pigment epithelium, layer of rods and cones, outer limiting membrane layer, outer nuclear layer, outer plexiform layer, inner nuclear layer, inner plexiform layer, ganglionic cells layer, nerve fibres layer and inner limiting membrane layer (Williams \& Warwick, 1980 and Fawcett, 1994). The neuronal elements of the retina are photoreceptors, horizontal cells, bipolar cells, amacrine cells and ganglion cells (Pycock, 1985)

In albino rat, the pigmented epithelium is a single layer of low cuboidal cells. Some are binucleated and the cell boundaries are ill defined. Large cells with large nuclei can also be present and multinucleated cells are commonly seen. No pigment granules can be detected (Bacon \& Niles, 1983). The retina of nocturnal animals is typically provided mainly with rods, whereas those of animals that are active by day have mostly cones. Rods are adapted to function in dim light and produce images that are composed of varying shades of black and white. Cones are adapted to function in bright light and are responsible for color vision. Thus albino rats have few cones and their color vision is poorly developed compared with man (Cormack, 1987). The outer limiting membrane consists of a thin line when seen with light microscope. With electron microscope this line is revealed to be due to alignment of desmosomes between Muller cells and adjacent parts of rod and cone cells (Kessel, 1998).

Outer nuclear layer consists of several layers of closely packed nuclei of rod and cone cells. Cone nuclei are formed of single row 
located close to the outer junctional zone, with exception of the region of the fovea which contains several rows (Cormack, 1987). Outer plexiform layer is a transition zone between the outer and the inner nuclear layers. It is the region of synaptic interplay between the photoreceptor, bipolar and horizontal cells. The rod axons end in oval invaginated rod spherules and the cone axons end in conical or pyramidal cone pedicles (Fawcett, 1994).

The inner nuclear layer is composed of three nuclear strata; horizontal cell nuclei form the outermost zone, then the nuclei and cell bodies of bipolar cells, Muller cells and the outer set of amacrine cells (Boycott \& Wassle, 1991 and Kolb, et al., 1992). Boycott \& Hopkins, 1993 and Williams et al., 1995 reported that, Bipolar cells are classified into two principal groups, rod and cone bipolar cells. Horizontal cells are classified into two classes called horizontal I and horizontal II in primates including human retina. Both classes are reported to contact rods and cones. Horizontal I cells are larger and have higher number of synaptic contact, but both classes have large pale nuclei, vacuolated cytoplasm and an organelle rich in ribosomes which is peculiar to them.

Reichenbach, et al., 1992 reported that Muller cells form much of the total retinal volume and fill the extra cellular space between neural elements. Their functions are similar to that of astrocytes, maintaining stability of retinal extra cellular environment, mechanical support of the neural retina, uptake of neurotransmitter, removal of debris and storage of glycogen. Muller cells have dense angular nuclei which lie in the inner nuclear layer. The processes of these cells extend from the internal to the external limiting membranes of the retina (Junqueira, et al., 1998).

Amacrine cells are named so because they lack axons. Each neuron has a cell body located either in the inner nuclear layer or in the outer aspect of the ganglion cell layer. Their cell bodies contain indented nuclei, much granular endoplasmic reticulum, ribosomes, microtubules and sometimes crystalline bodies (Williams \& Warwick, 1980).

The inner plexiform layer contains synaptic interplay between bipolar, amacrine and ganglion cells. Displaced amacrine cells are occasionally seen in this layer (Kessel, 1998).

Ganglion cells are the final pathway neurons of the retina. In albino rat the ganglion cells are large, pale cells and are arranged in discontinuous row (El-Rachkawy, 1984). They form a single layer in most of the retina but as they approach the macula they become more numerous. In the macula they are about 10 rows, diminishing again towards the fovea (Curcio \& Allen, 1990). 
The ganglion cells have one or two large dendrites and synapse with axon terminals of many bipolar neurons. Their cytoplasms contain many fibrils and chromatin granules, the latter appear as aggregations of cisterns of granular endoplasmic reticulum under the electron microscope. Subsurface cisterns, free ribosomes and agranular reticulum are also abundant (Williams and Warwick, 1980).

In rat retina, blood capillaries are present within inner plexiform, ganglion cell and nerve fiber layers (Kissen \& Bloodworth, 1961 and Villegas, 1964). The nerve fiber layer contains unmyelinated axons of ganglion cells together with processes of Muller cells and retinal blood vessels (Cormack, 1987). The inner limiting membrane is a traditional term because the electron microscope has revealed that it is not a membrane but it is composed of the expanded end feet of Muller cells and astrocytes, separated from the vitreous body by a complex thick basal lamina (Fawcett, 1994).

Monosodium glutamate is a widely used flavor enhancer (Ensminger, et al., 1995 and Walker \& Lupien, 2000). Nowadays monosodium glutamate is a widely used food additive as it enters in the preparation of dried canned soups, soya sauce, dried foods, processed meats, canned foods other than plain vegetables and fruits, frozen dinners. The world wide consumption rate of monosodium glutamate is more than 150 million pounds (67.5 million $\mathrm{kg}$ ) per year (Ellenhorn, et al., 1997).

During the last 25 years, the neurotoxicity of glutamate has been studied in various neuronal culture systems. Olney, 1969a reported that when high systemic doses of glutamate were administered to rodents, massive swelling of the neuronal cell bodies and dendrites were observed within 30 minutes. The swelling was followed by degeneration of organelles and nuclear pyknosis. Several days later the neurons become necrotic. Choi, 1992 in an in vitro study found that high concentration of glutamate causes swelling and degeneration of neurons.

Certain diseases as prolonged seizure activity (Olney, et al., 1969b), head and spinal cord injuries (Liu, et al., 1991) and cerebral ischemia (Lipton, 1994) are associated with excessive release of glutamate into extracellular space and subsequent neurotoxicity. Glutamate accumulation induces neuronal death by increasing the influx of $\mathrm{Ca}^{2+}$ through selective glutamate receptor channels (Choi \& Rothman, 1990; Brorson, et al., 1994 and Bonfoco, et al., 1995). Calcium triggers a cascade of reactions including free radical generation, lipid per oxidation, activation of proteases, phospholipases and endonucleases 
and transcriptional activation of apoptotic programs. Finally these reactions destroy the cells. When the cells are injured large amount of glutamate will be released and cause further damage (Kristian \& Siesjo, 1998; Atlante, et al., 2001 and Nishizawa, 2001).

The type of excitotoxic cell death observed depends on the intensity of the exposure and involve two temporal phases of necrosis and apoptosis, a feature that relies on mitochondrial physiology (Ankarcrona, et al., 1996; Nicotera \& Lipton, 1999; Gepdiremen,et al., 2001 and Sapolsky, 2001). Hu, et al., 1998 and Goldsmith, 2000 reported that glutamate neurotoxcity is characterized by time and dose dependent damage of many cell components leading to cell death.

In the study done by Lucas \& Newhouse, 1957, seventy suckling mice were daily injected subcutaneously with monosodium glutamate starting with $4 \mathrm{mg}$ on the $2^{\text {nd }}$ day postnatal followed by daily increase of $2 \mathrm{mg}$ up to the $17^{\text {th }}$ day postnatal. Mice were examined few hours after injection, showed pyknotic nuclei along the inner border of the future inner nuclear layer.

Reif-lehrer et al., 1975 reported that the retina is so sensitive to the toxic action of monosodium glutamate which can be observed few hours following administration. They noticed severe morphologic damage of the retina following administration of glutamate. Similar results were recorded by Sisk \& Kuwabara, 1985 and Ankarcrona, et al., 1995. They added that monosodium glutamate is known to cause intracellular swelling, necrosis and disappearance of most inner retinal neurons with concomitant thinning of inner retinal layers. The mitochondrial membranes collapsed, nuclei swollen and intercellular debris were scattered.

Following monosodium glutamate administration the following ultra structural changes could be observed in the retina: prominent mitochondrial alteration, loss of the mitochondrial membrane and swelling of the mitochondria. Some nuclei swelled and intracellular debris was scattered (Ankarcrona, et al., 1995; Green \& Kroemer, 1998 and Kristian \& Siesjo, 1998). Dimensions and shapes of the cells and nuclei were found to change. Some of the cells were irregular in shape. Some of the nuclei were also irregular or pyknotic. The perinuclear space was found to be enlarged. The heterochromatin condensed at the periphery. Some large vacuoles were spotted in the nuclei. A clear cytoplasmic matrix contained only a few mitochondria and free ribosomes. The mitochondrial cristae were rare or prominently thin or 
thick. Dilated cisterns of granular endoplasmic reticulum were observed (Esrefoglu, et al., 2003).

Ohguro, et al., 2002 studied the effect of high dietary intake of monosodium glutamate on the retinal morphology and function. Adult rats were fed regularly with diet containing large excess of monosodium glutamate. After one, three and six months of administration the rats were examined. In addition to marked reduction in the thickness of the retinal neuronal layers, there was significant accumulation of glutamate in the vitreous body, which may cause retinal cell destruction. Functionally, electroretinogram responses were reduced.

Following daily subcutaneous injection with monosodium glutamate Lucas \& Newhouse, 1957, found numbers of ganglion cell nuclei were pyknotic or showed rather pale staining of the nuclear chromatin network, and there was concomitant cytoplasmic shrinkage and loss of normal basophilic staining, the number of the ganglion cells was substantially reduced and the inner nuclear layer was only half of its normal thickness. The pigmented epithelium was never involved.

Ganglion cells are more sensitive to toxic effects caused by monosodium glutamate (Rigdon, et al., 1989; Chambille \& Serviere, 1993 and Chambille, 1998). Chambille \& Serviere 1993 and Chambille 1998 found that among the ganglion cell layer the displaced amacrine cells are less sensitive to the monosodium glutamate toxicity than ganglion cells. Only $30 \%$ of displaced amacrine cells were lost. The specific sensivity found in ganglion cells was not found in displaced amacrine cells.

On studying the effect of monosodium glutamate on the optic nerve, Lucas \& Newhouse, 1957 reported that the optic nerve appeared much thinner in hematoxylin and eosin stained sections in the treated animals with monosodium glutamate. The fiber bundles in the papilla were found to be narrowed and the number of glial cells was increased. Cohen, 1967 reported marked reduction of the number of the myelinated axons in the optic nerve from 25000 to $0-225$ nerve fibres. Seress, et al., 1984 noticed marked shrinking of the optic nerves and many myelinated as well as unmyelinated axons were lost after monosodium glutamate injection. Chambille, 1998 found that daily injection of monosodium glutamate during postnatal period induces retinal lesions, optic nerve degeneration with an alteration of the visual pathway.

Marked narrowing of the retinal vessels but spared the vitreous vessels following monosodium glutamate administration subcutaneously (Coulombre \& Coulombre, 1966 and Cohen, 1967). 


\section{MATERIALS and METHODS}

24 male newborn albino rats (Wistar strain) were used in the study. The animals were 2 days old and weighed $5-7$ grams. The animals were housed in the research laboratory of the department of anatomy, Assiut University at the ordinary room temperature in the normal daily light and darkness cycle. The animals were fed with normal mice chow and water ad-libitum. The animals were divided into two groups. Control group (12 animals) injected with saline only. Treated group (12 animals) treated with monosodium glutamate from the $2^{\text {nd }}$ to the $18^{\text {th }}$ day postnatal. Six animals were sacrificed and examined 24 hours after the last dose of treatment to detect the early effect of monosodium glutamate administration on the retina. The other six animals were sacrificed and examined at the age of two months to detect the delayed effect of monosodium glutamate administration on the retina.

Monosodium glutamate was given subcutaneously (Mistlberger \& Antle, 1999 and Goldsmith, 2000) in a dose of $4 \mathrm{mg} / \mathrm{gm}$ body weight (Park, et al., 2000 and Gonzalez-Burgos, et al., 2001). Twenty five grams of monosodium glutamate were dissolved in $500 \mathrm{ml}$ of saline so the final concentration was $50 \mathrm{mg}$ of monosodium glutamate in each 1 $\mathrm{ml}$ of saline. The treated 12 animals were weighed and injected with 4 $\mathrm{mg} / \mathrm{gm}$ body weight of monosodium glutamate from the $2^{\text {nd }}$ to the $18^{\text {th }}$ day postnatal. The animals of the control group were injected subcutaneously with saline from the $2^{\text {nd }}$ to the $18^{\text {th }}$ day postnatal.

After scarification the eyes were avulsed and placed in cold 2.5 gluteraldehyde. The cornea was punctured and then dissected away with iridectomy scissor. The lens was then removed and the remainder of the eye allowed fixing for one hour in cold 2.5 gluteraldehyde. The eyes were dehydrated in ethanol and embedded in epoxyresin. The embedded eyes were cleaved along the horizontal axis and the regions immediately temporal to the nerve head (central regions) were taken. Semi-thin sections ( 1 micron) and ultra-thin sections ( 0.07 microns) were done using ultra-microtome. Semi-thin sections were stained by toluidine blue and examined by light microscopy. Thickness of different layers of the retina was measured by using camera Lucida. Data for each group was presented in the mean \pm standard deviation. Statistical analysis was done using student t-test. Ultra-thin sections were stained by uranyl acetate 
and lead citrate (Reynolds, 1963) and were examined by electron microscope (Joel Jean 100C).

\section{RESULTS}

19-days old control albino rats (Fig. 1, 5, 7, 9\& 11. Table 1)

By light microscope the retina of the 19-days old control albino rats is formed of the following layers:

The epithelium is formed of a single layer of low cuboidal cells that rests on a basal lamina. The nuclei are spherical or elongated (Fig. $1 \& 5$ ). Its mean thickness is $0.007 \pm 0.001 \mathrm{~mm}$ (Table 1).

The photoreceptor cell layer is differentiated into outer and inner segments. The outer segment is thinner, longer and lighter in staining than the inner segment (Fig. 1\& 5). Its mean thickness is $0.04 \pm 0.0008$ mm (Table 1).

The outer limiting membrane is a thin zone which separates the photoreceptor layer from the outer nuclear layer (Fig. 1\& 5).

The outer nuclear layer is formed of the cell bodies of the photoreceptor cells (rods) which are 10: 15 rows. The nuclei are rounded and deeply stained (Fig. 1\& 7). The mean thickness is $0.07 \pm 0.009 \mathrm{~mm}$ (Table 1).

The outer plexiform layer appears as reticular layer which separates the outer nuclear layer from the inner nuclear layer. It is formed of the synapses between the axons of the photoreceptor cells and the dendrites of the bipolar cells which form with the horizontal and Muller cell processes a plexiform appearance (Fig. 1\& 9). The mean thickness is $0.02 \pm 0.001 \mathrm{~mm}$ (Table 1).

The inner nuclear layer consists of 3: 5 layers of cells. The cells of this layer are of different types, the horizontal, the bipolar, Muller and amacrine cells. The horizontal and the bipolar cells are scattered in the outer rows of the inner nuclear layer. The horizontal cells have large pale nuclei (Fig. 1\& 9). The bipolar cells have large rounded pale nuclei. Its mean thickness is $0.05 \pm 0.001 \mathrm{~mm}$ (Table 1). By electron microscopic examination of the inner and intermediate zones of the inner nuclear layer we can detect the ultrastructure of the amacrine and Muller cells. The Muller cell bodies are found in the intermediate rows and each has an angular dark nucleus with dark cytoplasm. The amacrine cells are found in the innermost zone of the inner nuclear layer. They are large and spherical cells containing large, pale, central and slightly indented 
nuclei. The cytoplasm of these cells shows numerous rough endoplasmic reticulum (Fig. 13).

The inner plexifom layer is a reticular layer which is found between the inner nuclear layer and the ganglionic cell layer (Fig. 1, 9\& 11). The mean thickness of this layer is $0.07 \pm 0.003 \mathrm{~mm}$ (Table 1). By electron microscopy, it is formed of synapses between the axons of the bipolar cells and the dendrites of the ganglionic cells and processes of the Muller cells (Fig. 13, 14\& 15).

In the ganglionic cell layer the ganglionic cells are arranged in single discontinuous row (Fig. 1\& 11). The mean thickness of this layer is $0.02 \pm 0.001 \mathrm{~mm}$ (Table 1). By electron microscopy, the ganglionic cells are large, pale cells with large rounded nuclei and granular unhomogenous chromatin. The cytoplasm has numerous ribosomes and rough endoplasmic reticulum. Frequent submembranous cisterns are also observed.

The nerve fiber layer is formed of the axons of the ganglionic cells (Fig. 11\& 15).

The internal limiting membrane limits the internal aspect of the retina (Fig. $11 \& 15$ ).

19-days old albino rats treated with monosodium glutamate (Fig. 2, $6,8,10 \& 12$. Table 1)

Significant reduction of different retinal layers is the main finding that can be observed in the treated 19 days old albino rats on comparing to the control one (Fig. 2, 6, 8, 10\& 12. Table 1).

Electron microscopic examination of the inner nuclear layer showed change in the shape and dimension of the amacrine cells with irregularity in their nuclear outline. Festoon like appearance and duplication of the nuclear membranes can be detected. The cytoplasm of these cells contains degenerative vacuoles and no cell organelles can be observed. Some degenerative vacuoles can also be observed in the Muller cells. The inner plexiform layer looses its reticular appearance (Fig. 16)

Electron microscopic examination of the ganglionic cells shows change in the shape and dimension of the cells and the nuclei, disturbance of the cellular membrane. The nuclear changes include indentation of the nuclear membranes, peripheral condensation of the chromatin with increase in the granularity of the chromatin as compared with the control cells. The cytoplasmic changes include watery cytoplasmic matrix containing vacuoles of multiple shape and size, 
rough endoplasmic reticulum and dilated submembranous cistern were observed (Fig.17).

Table 1: The Mean \pm SD of the thickness at different retinal layers of control and treated animals (19 days old).

\begin{tabular}{|c|c|c|c|}
\hline 19 days old & $\begin{array}{c}\text { Control } \\
\mathrm{N}=6\end{array}$ & $\begin{array}{c}\text { Treated } \\
\mathrm{N}=6\end{array}$ & $\mathrm{P}$ \\
\hline Epithelium & $0.007 \pm 0.001$ & $0.006 \pm 0.001$ & 0.6 \\
\hline Photoreceptor cell layer & $0.04 \pm 0.0008$ & $0.02 \pm 0.006$ & $0.03^{*}$ \\
\hline Outer nuclear layer & $0.07 \pm 0.009$ & $0.03 \pm 0.002$ & $0.03^{*}$ \\
\hline Outer plexiform layer & $0.02 \pm 0.001$ & $0.01 \pm 0.003$ & $0.04^{*}$ \\
\hline Inner nuclear layer & $0.05 \pm 0.001$ & $0.04 \pm 0.001$ & $0.02^{*}$ \\
\hline Inner plexiform layer & $0.07 \pm 0.003$ & $0.04 \pm 0.01$ & $0.04^{*}$ \\
\hline Ganglionic cell layer & $0.02 \pm 0.001$ & $0.01 \pm 0.001$ & $0.04^{*}$ \\
\hline
\end{tabular}

(N) number of animals per group.

(*) significance $(<0.05)$.

\section{2-months old control albino rats}

By light microscope the retina of the two months old control albino rats is formed of the following layers:

The epithelium is formed of a single layer of low cuboidal cells that rests on a basal lamina. The nuclei are spherical or elongated (Fig. 19). The mean thickness of this layer is $0.01 \pm 0.0001 \mathrm{~mm}$ (Table 2).

The photoreceptor cell layer is differentiated into outer and inner segments. The outer segment is thinner, longer and lighter in staining than the inner segment (Fig. 19). The mean thickness of this layer is 0.05 $\pm 0.01 \mathrm{~mm}$ (Table 2).

The outer limiting membrane is a thin zone which separates the photoreceptor cell layer from the outer nuclear layer (Fig. $19 \& 21$ ).

The outer nuclear layer is formed of the cell bodies of the photoreceptor cells (the rods) which are from 10: 15 rows. The nuclei are rounded and deeply stained (Fig. 21). The mean thickness of this layer is $0.1 \pm 0.007 \mathrm{~mm}$ (Table 2).

The outer plaxiform layer appears as a reticular layer which separates the outer nuclear layer from the inner nuclear layer (Fig. 23). It is formed of the synapses between the axons of the photoreceptor cells and the dendrites of the bipolar cells which form with the horizontal and Muller cell processes a plexiform appearance. The mean thickness of this layer is $0.02 \pm 0.0009 \mathrm{~mm}$ (Table 2). 
The inner nuclear layer consists of 3: 5 layers of cells (Fig. 23). The mean thickness of this layer is $0.06 \pm 0.001 \mathrm{~mm}$ (Table 2). The cells of this layer are of different types; the horizontal, bipolar, Muller and amacrine cells. The horizontal and the bipolar cells are scattered in the outer rows of the inner nuclear layer. The horizontal cells have large, pale nuclei. The bipolar cells have large rounded pale nuclei. By electron microscopy, the amacrine cells are found in the innermost zone of the inner nuclear layer. They are large and spherical cells with large, central, pale and slightly indented nuclei. Muller cells with dark nuclei and dark cytoplasm can be observed (Fig. 25).

The inner plexiform layer appears as a reticular layer which is found between the inner nuclear layer and ganglionic cell layer (Fig. 23). The mean thickness of this layer is $0.07 \pm 0.02 \mathrm{~mm}$ (Table 2). By electron microscopy, it is formed of synapses between the axons of the bipolar cells and the dendrites of the ganglionic cells and the processes of the Muller cells (Fig. $26 \& 27$ ).

The ganglionic cells in the ganglionic cell layer are arranged in a single discontinuous row (Fig. 23). The mean thickness of this layer is $0.02 \pm 0.006$ (Table 2). By electron microscopy, the ganglionic cells are large, pale cells with large rounded nuclei and granular unhomogenous chromatin. Frequent submembranous cisterns can be observed (Fig. 26 \& 27).

The nerve fiber layer is formed of the axons of the ganglionic cells (Fig. 26).

The internal limiting membrane limits the internal aspect of the retina (Fig. 26).

\section{2-Months old albino rats treated with monosodium glutamate}

By light microscope the retina of treated 2 months old albino rat shows marked reduction in thickness of different retinal layers (Fig. 20, 22\& 24). The nuclei in the outer nuclear layer are less compact and non homogenous in size and shape as compared with control. The mean thickness of different retinal layers is significantly reduced (Table 2). Electron microscopic examination of the inner nuclear layer of the treated 2 months old albino rats shows shrunken amacrine cells with marked indentation of the nuclear membrane. No cell organelles can be observed (Fig. 28).

Electron microscopic examination of the ganglionic cell layer of the retina of the treated 2 months old albino rats shows shrunken ganglion cells with smaller nuclei and hazy nuclear membrane. No cell 
organelles can be detected. Some degenerative vacuoles are present (Fig.29 \&30).

Table 2: The Mean \pm SD of the thickness of different retinal layers of control and treated animals ( 2 months old).

\begin{tabular}{|c|c|c|c|}
\hline 2 months old & $\begin{array}{c}\text { Control } \\
\mathrm{N}=6\end{array}$ & $\begin{array}{c}\text { Treated } \\
\mathrm{N}=6\end{array}$ & $\mathrm{P}$ \\
\hline Epithelium & $0.01 \pm 0.0001$ & $0.01 \pm 0.003$ & 0.5 \\
\hline Photoreceptor cell layer & $0.05 \pm 0.01$ & $0.03 \pm 0.003$ & $0.03^{*}$ \\
\hline Outer nuclear layer & $0.1 \pm 0.007$ & $0.03 \pm 0.01$ & $0.01^{*}$ \\
\hline Outer plexiform layer & $0.02 \pm 0.0009$ & $0.01 \pm 0.005$ & $0.04^{*}$ \\
\hline Inner nuclear layer & $0.06 \pm 0.001$ & $0.01 \pm 0.002$ & $0.01^{*}$ \\
\hline Inner plexiform layer & $0.07 \pm 0.02$ & $0.01 \pm 0.01$ & $0.03^{*}$ \\
\hline Ganglionic cell layer & $0.02 \pm 0.006$ & $0.004 \pm 0.002$ & $0.02^{*}$ \\
\hline
\end{tabular}

(N) number of animals per group.

(*) significance $(<0.05)$.

\section{DISCUSSION}

In the present study, neonatal albino rats were chosen for several factors including easy handling and manipulation, great numbers can be obtained as they are fast breading mammalians. Neonatal rats were chosen as comparative studies indicated that the neonatal rodents are most sensitive to neuronal injury than older (Walker \& Lupien, 2000). The inner layers of the retina were chosen to study monosodium glutamate toxicity using electron microscope because they readily absorb glutamate from a glucose saline medium (Stern, et al., 1949). The monosodium glutamate dose used was given according to Rigdon, et al., 1989; Brankack \& Klingberg, 1990 and Park, et al., 2000.

In this study the effects of monosodium glutamate were time dependent, as marked destruction was observed in the inner layers of the retina examined at the age of two months in comparison with those examined immediately after the last dose of treatment at the age of 19 days old. This agrees with the studies done by Du, et al., 1997 and ElIdrissi \& Trenker, 1999. The molecular mechanism of this neurotoxicity has been reviewed by Lynch \& Dawson, 1994 and can be summarized as follows: $\mathrm{Ca}^{2+}$ entry through both excitatory amino acid neurotransmitter operated and voltage operated $\mathrm{Ca}^{2+}$ channels, together with $\mathrm{Ca}^{2+}$ release 
from intracellular stores result in uncontrolled activation of neuronal protein kinases, phospholipases and proteases and nitric oxide synthesis. These consequent proteolysis, lipid peroxidation and free radical formation result in the death of neurons.

In the present study, inspite of affection of different layers of the retina, as shown by significant reduction in their thickness, complete destruction of any layer did not occur in the treated two age groups. This comes in agreement with Cohen, 1967 who found that following subcutaneous administration of monosodium glutamate to neonatal mice, the effects of glutamate appeared to represent randomized destruction, in that some of everything persists. Protection of some neurons from the toxic effects of glutamate was explained by Gonzalez-Burgos, et al., 2001. They found two effects for monosodium glutamate to neonatal rats: (1) An excitotoxic effect leading to cell death and (2) A secondary neuroprotective effect arising from the proliferation of glial cells and their subsequent uptake of glutamate that favours survival of the remaining neurons. The same was found by Wong \& Hugues, 1987, Azuma, et al., 1989 and Ketenmann \& Ransom, 1995.

Another explanation as regard the neuronal survival has been suggested as a result of the involvement of the reactive free-radical nitric oxide which is synthesized by nitric oxide synthetase (Bredt, et al., 1990 and Kiedrowski, et al., 1992). Nitric oxide can act as a neuronal messenger (Garthwaite, 1991) as well as a toxin for neighbouring neurons at high concentrations (Dawson, et al., 1991). Neurons containing nitric oxide synthetase were protected by the neutralization by super-oxide ions (Garthwaite, 1991 and Snyder \& Bredt, 1991).

The present study revealed that the significant reduction in the thickness was more marked in the inner layers of the retina as compared with the outer layers in the animals examined at the age of 2 months. This selective destruction was observed by Ohguro, et al., 2002, and they explained this by greater accumulation of glutamate in the vitreous cavity.

\section{The epithelium:}

In the present study the epithelium of the retina of the control albino rats is formed of single layer of low cuboidal cells resting on basal lamina that is located towards the choroid. The nuclei are spherical or ovoid. No detectable melanin pigment in the epithelial cells of albino rats. This comes in agreement with the description of Ts'o \& Friedman 1967, Bacon \& Niles 1983 and Watzke, et al., 1993.

In the treated groups the histological picture of the epithelium is 
more or less similar to that described in the control group. In addition, the reduction in the thickness in this layer is non significant. This indicates that the epithelium has not been affected following monosodium glutamate administration. This means that always neurons were the target following monosodium glutamate administration (Massey \& Redburn 1987 and Chambille \& Serviere 1993).

\section{The photoreceptor layer:}

In semithin section, the photoreceptor layer of the control groups is formed of outer and inner segments. The outer one is arranged in parallel fashion and is thinner and darker in staining compared with the inner one. This is in accordance with the description of Bailey, 1978. Walls 1942 and Warwick, 1976 stated that the retina of rats is provided mainly with rods. Rods are adapted to function in dim light and produce images that are compassed of varying shades of black and white. No fovea centralis can be detected in the albino rat retina.

In the treated two age groups, significant reduction in the thickness of the photoreceptor layer can be observed. This denotes that this layer is vulnerable to monosodium glutamate toxicity. This comes in agreement with Sisk \& Kuwabara, 1985 as they found that by two months post injection of monosodium glutamate to neonatal albino rats, there were degenerative changes in rod spherules and some loss of photoreceptor nuclei.

Receptor sparing was reported by Potts, et al., 1960 and Potts, 1965. Receptor sparing was explained by Cohen 1967 by undamaged choroid blood supply or some intrinsic resistance of these cells. He found that almost all the receptors are entered by neurites despite destruction of the inner nuclear layer. Miller \& Slaughter, 1986 and Ehinger \& Dowling, 1987 explained the affection of some neurons and sparing of others as follows, the excitatory amino acid, glutamate is the most potent neurotransmitter of the retina of mammals. In the retina, there is now much physiological evidence suggesting that the synaptic transmission from photoreceptors to $5-10 \%$ of ganglion cells is of excitatory amino acid type. This explanation denotes also that some of the photoreceptor cells escape the glutamate toxicity.

\section{The external limiting membrane:}

The present study shows that the external limiting membrane of both the control and treated animals appears as a line of demarcation between the inner segments of the photoreceptors and their cell bodies. This description of the control animals comes in agreement with Snell, 1984 and Cormack, 1987. 


\section{The outer nuclear layer:}

The outer nuclear layer of the control albino rats is formed of 10: 15 layers of cells. The nuclei are similar in appearance, being rounded and deeply stained with dense chromatin. This comes in agreement with El-Rachkawy, 1984.

In the treated animals, significant reduction in the thickness of this layer is observed. The affection of the outer nuclear layer can be explained in the same manner of the affection of the photoreceptor layer as the outer nuclear layer represents several rows of the photoreceptor cell bodies. In agreement with that, Lucas \& Newhouse 1957 (in mice) stated that the outer nuclear layer was little affected, although the final number of rows of nuclei appeared slightly reduced.

\section{The outer plexiform layer:}

The outer plexiform layer of the control animals appears as a transition zone between the outer and the inner nuclear layers and has a reticular appearance. This description is in agreement with that of ElRachkawy in 1984. Cormack, 1987 considered this layer as region of complex synaptic interactions between the axons of photoreceptor cells and the dendrites of the bipolar cells. The dendrites of the bipolar cells branch into terminal networks giving this layer a plexiform appearance.

In the treated animals, significant reduction in the thickness of the outer plexiform layer is observed. The affection of this layer may be explained as a result of affection of both the photoreceptor and the inner nuclear layers as this layer represents the site of synapses between the photoreceptor and the bipolar cells. On the other hand Cohen 1967(in mice), found that the outer plexiform layer was not affected. $\mathrm{He}$ suggested that an adaptation of the residual inner nuclear layer occurred to synapse more receptor.

\section{The inner nuclear layer:}

In the present study the inner nuclear layer contained 3: 5 rows of cells. This result coincides with Braekevelt \& Hollenberg, 1970. By electron microscopy, the amacrine cells were found in the innermost zone of the inner nuclear layer. They are large and spherical cells with large, central, pale and slightly indented nuclei. Their cytoplasm has numerous mitochondria and rough endoplasmic reticulum. This agrees with the description of Villegas, 1964 (human) and El-Rachkawy, 1984 (albino rat).

The Muller cells are found in the intermediate zone of the inner nuclear layer. They have angular dark nuclei with dark cytoplasm. This agrees with the description of Hogan, et al., 1971 (human). 
The inner nuclear layer of the treated 19 days old albino rats showed changes in the shapes and dimensions of the amacrine cells with irregularity in their nuclear membranes. Lucas \& Newhouse 1957 reported that the cells of the internal surface of the inner nuclear layer were more susceptible to glutamate toxicity than those of the external surface. These prominent glutamate induced ultrastructural changes are similar to that described by Esrefoglu, et al., 2003.

In this study an apparent vacuolization of the cytoplasm of the examined cells is characteristic of the early excitotoxic events of monosodium glutamate. This comes in agreement with Bindokas \& Miller, 1995 and Kristian \& Siesjo, 1998. They reported that excitotoxic cell injury caused by glutamate was originally assumed to be osmolytic. Early cell swelling is usually reversible. The cells exposed to glutamate show a type of delayed cell death. Increases in intracellular $\mathrm{Ca}^{2+} \& \mathrm{Na}^{+}$ lead to death of neurons whose first evidence is the swelling of the soma.

Dietrich, et al., 1992 and Matyja, 2000 stated that an apparent microvacuolization of the cytoplasm of the affected cells is characteristic of early excitotoxicty. During acute neuronal injury swollen neurons commonly display increased number of cytoplasmic vacuoles.

Marked vacuolization of the cytoplasm in the examined cells of our study suggests that the early effect of monosodium glutamate administration on the retina seems to be necrotic in nature. In agreement with this observation, Fujikawa, et al., 2000 reported that cellular edema was an early event of necrosis.

In accordance with this opinion Isaev, et al., 1996 had shown that acute glutamate toxicity predominantly induced necrotic changes and glutamate exposure $(15 \mathrm{~min})$ caused considerable ultrastructural alteration.

Recently growing evidence showed that mitochondrial dysfunction is an important factor in the cascade of glutamate neurotoxicity. Chronic mitochondrial inhibition and dysfunction result in neuronal death which is mediated by glutamate excitotoxicity (Ankarcrona, et al., 1995 and Van Westerlaak, et al., 2001).

Nicholls \& Budd, 1988 added that mitochondrial $\mathrm{Ca}^{2+}$ accumulation is a necessary intermediate in glutamate induced neuronal death. On exposure to glutamate the neurons undergo a delayed $\mathrm{Ca}^{2+}$ deregulation which precedes and predicts cell death (Castilho, et al., 1999).

Massive calcium accumulation triggers mitochondrial damage. Exposure of mitochondria to calcium and glutamate cause them to swell 
and to release intramitochondrial components into the medium (Kristian \& Siesjo, 1998). Swelling of the mitochondria is characterestic of early excitotoxic events. In acute neuronal injury mitochondria show enlargement with ruptured cristae (Dietrich, et al., 1992 and Matyja, 2000).

During and shortly after exposure to glutamate, a subpopulation of neurons die by necrosis (which is observed in the treated 19 days animal). Glutamate induces either early necrosis or delayed apoptosis. Wood \& Bristow, 1998 reported that neurons surviving early necrotic phase undergo apoptosis. Mitochondrial membrane potential collapses, nuclei swell, and intracellular debris scatter in incubation medium.

When the mitochondria break down, releasing toxic chemicals into cytoplasm, these toxins poison the cell causing destruction of other cell structures including nucleus (Wood \& Bristow, 1998 and Honda, et $a l ., 2001)$. This can be observed in the animals examined later on at the age of two months where marked destruction of the cells in the inner nuclear layer is observed and no cell organelles can be detected.

The observations were confirmed by Wyllie \& Duvall, 1992 who stated that in apoptosis the cells generally lose their volume. Also, they added that in contradistinction to necrosis, mitochondria don't undergo swelling and rupture of the internal membrane during apoptosis.

\section{The internal plexiform layer:}

In the present study the internal plexiform layer is a zone between the inner nuclear layer and the ganglion cell layer. This zone has a reticular appearance and represents the site of synapses between the processes of bipolar, ganglion, amacrine and Muller cells. This agrees with Braekevelt \& Hollenberg, 1970 (rat); Hogan, et al., 1971 and Kessel, 1998 (human).

In the treated 19 days old albino rats the inner plexiform layer looses its characteristic reticulated appearance. This comes in agreement with Dietrich, et al., 1992 and Matyja, 2000 who suggested that the early effect of glutamate toxicity is necrotic in nature.

In the treated 2 months old albino rats marked destruction of the synapses is present and this comes in agreement with the marked destruction of the inner nuclear and ganglion cell layers in the older animals.

\section{The ganglion cell layer:}

The present study shows that the ganglion cells of the control animals are arranged in a single discontinuous row. In ultrathin section, they are large, pale cells with large rounded nuclei and granular 
unhomogenous chromatin. The cytoplasm of these cells has numerous ribosomes and rough endoplasmic reticulum. Subsurface cisterns are observed in these cells. This agrees with Cohen, 1967 (mice) and Spoerri \& Glees, 1977 (monkey), El-Rachkawy, 1984 (albino rat) and Junqueira, et al., 1998 (human).

In this model of monosodium glutamate neurotoxicity the ganglion cells are markedly affected in the two treated age group. This comes in agreement with the studies done by Siliprandi et al., 1992 (adult rat), Chambille \& Serviere, 1993 and Chambille, 1998 (golden hamster).

The nuclei of the ganglion cells of the treated 19 days old albino rats show peripheral condensation of the chromatin with increase in the granularity of the chromatin as compared with the control. This comes in agreement with Isaev, et al., 1996; Bezvenyuk et al., 2000; and Esrefoglu, et al., 2003. They reported that glutamate excito-toxicity is associated with extensive chromatin condensation.

Swelling of the endoplasmic reticulum is noticed in the examined cells of the 19 days old albino rats. This is in agreement with Segal \& Skolnick, 2000 and Atlante, et al., 2001. They considered this ultrastructural sign as a characteristic event which occurs during the glutamate toxicity.

Kristian \& Siesjo, 1998 reported that the endoplasmic reticulum is an important source of calcium. When cell activity leads to an excessive rise in $\mathrm{Ca}^{2+}$, the mitochondria may accumulate calcium. An uncontrolled release of calcium from the endoplasmic reticulum is believed to predispose to cell damage.

As regard monosodium glutamate toxicity, Espinar, et al., 2000 reported that neuronal injury induced by glutamate administration is characterized by progressive karyolysis and cytolysis. At early stages of cellular damage the nucleoplasm showed a fine, homogenous granularity with occasionally recognizable nucleolus. This could be observed in the ganglion cells of the treated 19 days old albino rats.

These early changes are followed by progressive degeneration of the cytoplasmatic organelles including disappearance of specific ultrastructural features with progressive shrinkage of the nucleus. The nuclear membrane exhibiting convolutions and progressive condensation of the cytoplasm in the areas adjacent to the nucleus. These ultrastructural changes can be observed in the cells of both the ganglionic cell and inner nuclear cell layers of the treated 2 months old albino rats. 
According to Cohen, 1967, surviving ganglion neurons belong to a population of small ganglion cells. Marani, et al., 1984 described them as belonging to a class of intermediate cell size and Van- Rijn, et al. 1986 stated that all cell classes could be affected by monosodium glutamate treatment. In our experiment, it is not possible to form classes distinguishable in terms of perikaryal size and no differentiation of the types of ganglion cells is established on the basis of morphological parameters such as the length and number of dendritic segments or area of dendritic fields. Therefore, it is difficult to qualitatively estimate the effects of treatment and to conclude that it preferentially affects a given morphologic type of ganglion cell.

\section{The nerve fibre layer:}

In the present study the nerve fibre layer of the retina of the control and treated albino rats is formed of the axons of the ganglionic cells, this comes in agreement with Cormack, 1987.

\section{The internal limiting membrane:}

The internal limiting membrane of both the control and treated 19 days and two months old animals limits the internal aspect of the retina; this description comes in agreement with Cormack, 1987.

\section{LEGENDS}

Fig. 1: A semithin section of the retina of 19 days old control albino rat shows: layer of epithelium (E), photoreceptor layer (P), outer nuclear layer (ONL), outer plexiform layer (OPL), inner nuclear layer (INL), inner plexiform layer (IPL) and ganglionic cell layer (GL).

(Toluidine blue X400)

Fig. 2: A semithin section of 19 days old albino rat treated with monosodium glutamate shows part of the choroid $(\mathrm{Ch})$ and layers of the retina: layer of epithelium (E), photoreceptor layer $(\mathrm{P})$, outer nuclear layer (ONL), outer plexiform layer (OPL), inner nuclear layer (INL), inner plexiform layer (IPL), ganglionic cell layer (GL). (Toluidine blue X 400)

Fig. 3: A semithin section of the retina of two months old control albino rat shows: layer of epithelium (E), photoreceptor layer $(\mathrm{P})$, outer nuclear layer (ONL), outer plexiform layer (OPL), inner nuclear layer (INL), inner plexiform layer (IPL) and ganglionic cell layer (GL).

(Toluidine blue X 400)

Fig. 4: A semithin section of the retina of two months old albino rat treated with monosodium glutamate shows: layer of epithelium 
(E), photoreceptor layer (P), outer nuclear layer (ONL), outer plexiform layer (OPL), inner nuclear layer (INL), inner plexiform layer (IPL) and Ganglionic cell layer (GL).

(Toluidine blue X 400)

Fig. 5: A semithin section of the retina of 19 days old control albino rat shows: layer of epithelium (E), photoreceptor layer, which divided into outer segment $\mathrm{P}(\mathrm{O})$ and inner segment $\mathrm{P}(\mathrm{i})$ and part of outer nuclear layer (ONL). $\quad$ (Toluidine blue X1000)

Fig. 6: A semithin section of the retina of 19 days old rat treated with monosodium glutamate shows: layer of epithelium (E), photoreceptor layer, which divided into outer segment $\mathrm{P}(\mathrm{O})$ and inner segment $\mathrm{P}(\mathrm{i})$ and part of outer nuclear layer (ONL). Notice the reduction of thickness in both segments of the photoreceptor layer in comparison with fig. 5 .

(Toluidine blue X1000)

Fig. 7: A semithin section of the retina of 19 days old control albino rat shows the outer nuclear layer (ONL). The nuclei are nearly rounded and deeply stained.

(Toluidine blue X1000)

Fig. 8: A semithin section of the retina of 19 days old rat treated with monosodium glutamate shows: photoreceptor layer, which divided into outer segment $\mathrm{P}(\mathrm{O})$ and inner segment $\mathrm{P}(\mathrm{i})$, outer nuclear layer $(\mathrm{ONL})$, outer plexiform layer (OPL) and part of the inner nuclear layer (INL). Notice the reduction of thickness in the inner nuclear layer in comparison with fig. 7.

(Toluidine blue X1000)

Fig. 9: A semithin section of the retina of 19 days old control albino rat shows the outer plexiform layer (OPL), the inner nuclear layer (INL) and the inner plexiform layer (IPL). The outer plexiform layer and inner plexiform layer appear reticular.

(Toluidine blue X1000)

Fig. 10: A semithin section of the retina of 19 days old rat treated with monosodium glutamate shows: part of the inner segment $\mathrm{P}(\mathrm{i})$ of the photoreceptor layer, outer nuclear layer (ONL), outer plexiform layer (OPL), inner nuclear layer (INL) and inner plexiform layer (IPL). Notice the reduction of thickness in these layers in comparison with fig. 9. (Toluidine blue X1000)

Fig. 11: A semithin section of the retina of 19 days old control albino rat shows the inner nuclear layer (INL) and the ganglion cell layer (GL). The inner plexiform layer appears reticular. The ganglion 
cell layer consists of discontinuous row of ganglion cells which has large rounded nuclei.

(Toluidine blue X1000)

Fig. 12: A semithin section of the retina of 19 days old rat treated with monosodium glutamate shows: part of the inner segment $\mathrm{P}(\mathrm{i})$ of the photoreceptor layer, outer nuclear layer (ONL), outer plexiform layer (OPL), inner nuclear layer (INL), inner plexiform layer (IPL) and the ganglion cell layer (GL). Notice the reduction of thickness in these layers in comparison with fig. 11. Notice also absence of the ganglion cells.

(Toluidine blue X1000)

Fig. 13: An electron micrograph of the inner nuclear layer and inner plexiform layer (IPL) of the 19 days old control albino rat. Amacrine cells (AC) show large indented nuclei $(\mathrm{N})$. The cytoplasm of these cells contains numerous rough endoplasmic reticulum (rER). Muller cell can be also observed (MC).

(X 4000)

Fig. 14: An electron micrograph of the retina of 19 days old control albino rat shows inner limiting membrane (ILM), nerve fiber layer (NF), ganglionic cell layer and inner plexiform layer (IPL). The ganglionic cells (GC) show large rounded nuclei (N) with granular unhomogenous chromatin. Rough endoplasmic reticulum (rER) and submembranous cisterns (C) can be observed in the cytorplasm of these cells. A Muller cell (MC) can be detected.

(X 4000)

Fig. 15: An eletronmicrograph of the retina of 19 days old control albino rat shows ganglionic cell layer and inner plexiform layer (IPL). The cytoplasm of the ganglionic cell (GC) shows rough endoplasmic reticulum (rER), ribosomes $(\mathrm{r})$ and frequent submembranous cisterns (c).

(X 8000)

Fig. 16: An electron micrograph of the inner nuclear layer and inner plexiform layer (IPL) of the retina of 19 days old albino rat treated with monosodium glutamate. The amacrine cells (AC) show festoon like appearance (\#), duplication of the nuclear membrane $(*)$ and no cell organelles. Degeneratsive vacuoles (V) can be observed in the cytoplasm of the amacrine cells (AC) and Muller cells (MC).

(X 4000)

Fig. 17: An electron micrograph of ganglionic cell layer in the retina of 19 days old albino rat treated with monosodium glutamate. The nucleus $(\mathrm{N})$ of the ganglionic cell (GC) shows peripheral condensation and increased granularity of the chromatin and 
the cytoplasm shows degenerative vacuoles (V), rough endoplasmic reticulum (rER) and dilated cisterns (C). (X 4000)

Fig. 18: An electrom micrograph of ganglionic cell layer and inner plexiform layer (IPL) of 19 days old albino rats treated with monosodium glutamate. The nucleus $(\mathrm{N})$ of the ganglionic cell (GC) shows indentation of its nuclear membrane (*). Dilated cisterns of rough endoplasmic reticulum (rER), ribosomes $(r)$, mitochondria $(\mathrm{m})$ and dilated submembranous cisterns $(\mathrm{C})$ are observed in the cytoplasm.

(X 8000)

Fig. 19: A semithin section of the retina of 2 months old control albino rat shows: layer of epithelium (E), photoreceptor layer, which divided into outer segment $\mathrm{P}(\mathrm{O})$ and inner segment $\mathrm{P}(\mathrm{i})$ and part of outer nuclear layer (ONL). (Toluidine blue X1000)

Fig. 20: A semithin section of the retina of 2 months old rat treated with monosodium glutamate shows: layer of epithelium (E), photoreceptor layer, which divided into outer segment $\mathrm{P}(\mathrm{O})$ and inner segment $\mathrm{P}(\mathrm{i})$ and part of outer nuclear layer (ONL). Notice the reduction of thickness in both segments of the photoreceptor layer in comparison with fig. 19.

(Toluidine blue X1000)

Fig. 21: A semithin section of the retina of 2 months old control albino rat shows the outer nuclear layer (ONL) and part of inner segment of photoreceptor layer $\mathrm{P}(\mathrm{i})$ and part of outer plexiform layer (OPL). The nuclei of the outer nuclear layer are nearly rounded and deeply stained.

(Toluidine blue X1000)

Fig. 22: A semithin section of the retina of 2 months old rat treated with monosodium glutamate shows: part of inner segment $\mathrm{P}(\mathrm{i})$ of photoreceptor layer, outer nuclear layer (ONL) and part of outer plexiform layer (OPL). Notice the reduction of thickness in the inner nuclear layer in comparison with fig. 21.

(Toluidine blue X1000)

Fig. 23: A semithin section of the retina of 2 months old control albino rat shows part of outer nuclear layer (ONL), the outer plexiform layer (OPL), the inner nuclear layer (INL), the inner plexiform layer (IPL) and ganglionic cell layer (GL). The outer plexiform layer and inner plexiform layer appear reticular. The ganglionic cells have large nearly rounded nuclei.

(Toluidine blue X1000)

Fig. 24: A semithin section of the retina of 2 months old rat treated with monosodium glutamate shows: part of the outer nuclear layer 
(ONL), outer plexiform layer (OPL), inner nuclear layer (INL) and inner plexiform layer (IPL). Notice the reduction of thickness in these layers in comparison with fig. 23. The ganglionic cells are absent from the field.

(Toluidine blue X1000)

Fig. 25: An electron micrograph of the inner nuclear layer of the retina of 2 months old control albino rat. The inner nuclear layer shows amacrine cells (AC) with large and indented nuclei $(\mathrm{N})$. Muller cells (MC) with dark nuclei $(\mathrm{N})$ and dark cytoplasm are present.

(X 4000)

Fig. 26: An electron micrograph of the internal limiting membrane (ILM), nerve fiber layer (NF), ganglionic cell layer and inner plexiform layer (IPL) of the retina of 2 months old control albino rat. The ganglionic cell (GC) shows large rounded nucleus $(\mathrm{N})$, granular unhomogenous chromatin, rough endoplasmic reticulum (rER) and frequent submembranous cisterns $(\mathrm{C})$.

(X 4000)

Fig. 27: An electron micrograph of the ganglionic cell layer and inner plexiform layer (IPL) of the retina of two months control albino rat. The nuclei of ganglionic cells (GC) show granular non homogenous chromatin and nuclear rough endoplasmic reticulum (rER).

(X 8000)

Fig. 28: An electron micrograph of the inner nuclear layer and inner plexiform layer (IPL) of the retina of two months old albino rat treated with monosodium glutamate. Shrunken amacrine cells (AC) with marked indentation of the nuclear membrane $(*)$. Muller cell (MC) is observed.

(X 4000)

Fig. 29: An electron micrograph of the inner limiting membrane (ILM), nerve fiber layer (NFL), ganglionic cell layer and inner plexiform layer (IPL) of the retina of 2 months old albino rat treated with monosodium glutamate. Shrunken ganglion cells (GC) with shrunken nuclei (N) and hazy nuclear membrane can be observed. Some degenerative vacuoles (V) and displaced amacrine cell (AC) are present.

(X 4000)

Fig. 30: An electron micrograph of the ganglionic cell layer and nerve fibre layer (NF) of the retina of 2 months old albino rat treated with monosodium glutamate. The ganglionic cell (GC) shows hazy nuclear membrane and no cell organelles can be detected. The nuclei of the displaced amacrine cells can be seen. 


\section{REFERENCES}

Ankarcrona, M.; Dypbukt, J.M.; Bonfoco, E.; zhivotovsky, B.; Orrenius, S.; Lipton, S.A. and Nicotera, P. (1995): Glutamate induced neuronal death: a succession of necrosis or apoptosis depending on mitochondrial function. Neuron, Oct; 15(4): 961 $-973$.

Ankarcrona M.; Dypbukt, J.M.; Orrenius, S. and Nictera, P. (1996): Calcineurin and mitochondrial function in glutamate-induced neuronal cell death. FEBS Lett., 394: 321 - 324.

Atlante A.; Calissano P.; Bobba A.; Giannattasio, S.; Marra, E. and Passarella S. (2001): Glutamate neurotoxicity, oxidative stress and mitochondria. FEBS Lett., 497: $1-5$.

Azuma, N.; Kawamura, M. and Kohsaka, S. (1989): Morphological and immunohistochemical studies on degenerative changes of the retina and the optic nerve in neonatal rats injected with monosodium-L-glutamate. Nippon Ganka Gakkai Zasshi. Jan; 93(1): $72-79$.

Bacon, R.L. and Niles, N.R. (1983): Medical histology: a test-atlas with introductory pathology. Springer-Verlag, New-York, Heidelberg and Berlin.

Bailey, F.R. (1978): Bailey's text book of histology. Baltimore, Williams and Wilkins, London, $745-758$.

Bezvenyuk, Z.; Suuronen, T.; Salminen, A. and Solovyan, V. (2000): Protective effect of suramin against cell death in rat cerebellar granuler neurons and mouse neuroblastoma cells. Neuroscience Lett., 292: 111 - 114.

Bindokas, V.P. and Miller, R.J. (1995): Excitotoxic degeneration is initiated at non random sites in cultured rat cerebellar neurons. J. Neurosci., 15: 6999- 7011.

Bonfoco, E.; Krainc, D.; Ankacrona, M.; Nicotera, P. and Lipton, S.A. (1995): Apoptosis and necrosis: two distinct events induced respectively by mild and intense insults with N-methyl-Daspartate or nitric oxide/superoxide in cortical cell cultures. Proc. Nat. acad. Sci. USA., 92: 7162 - 7166.

Boycott, B.B. and Wassle, H. (1991): Morphological classification of bipolar cells of the primate retina. Eur. J. Neurosci., 3: 1069 1088. 
Boycott, B.B. and Hopkins J.M. (1993): Cone synapses of a flat diffuse cone bipolar cell in the primate retina. J. Neurocytol., 22: $765-$ 778.

Braekevelt, C.R. and Hollenberg, M.J. (1970): Development of the retina of the albino rat. Am. J. Anat., 127: $281-302$.

Brankack, J. and Klingberg, F. (1990): Visually evoked responses in the primary cortex of rats are permanently changed by early postnatal treatment with monosodium-L-glutamate. Biomed. Biochem. Acta, 49(6): 473-480.

Bredt, D.S.; Hwang, P.M. and Snyder, S.H. (1990): Localization of nitric oxide synthase indicating a neural role for nitric oxide. Nature, 347: 768-770.

Brorson J.R.; Manzolillo, P.A. and Miller, R.J. (1994): Ca2+ entry via AMPA/K receptors and excitotoxicity in cultured cerebellar purkinje cells. J. Neurosci., 14: $187-197$.

Castilho, R.F.; Ward, M.W. and Nicholls, D.G. (1999): Oxidative stress, mitochondrial function and glutamate excitotoxicity in cultured cerebellar granule cells. J. Neurochem., 72: $1391-1401$.

Chambille, I. and Serviere J. (1993): Neurotoxic effects of neonatal injections of monosodium L-glutamate on the retinal ganglion cell layer of the golden hamster. Anatomical and functional consequences on the circadian system. J. Comp. Neurol., 338: $67-82$.

Chambille, I. (1998): Retinal ganglion cells expressing the FOS protein after light stimulation in the syrian hamster are relatively insensitive to neonatal treatment with monosodium glutamate. J. Comp. Neurol, 392: 458-467.

Choi, D.W. (1992): Excitotoxic cell death. J. Neurobiol., 23: 1261 1276.

Choi, D.W. and Rothman, S.M. (1990): The role of glutamate neurotoxicity in hypoxic-ischemic neuronal death. Annu. Rev. Neurosci., 13:171-182.

Cohen, A.I. (1967): An electron microscopic study of the modification by monosodium glutamate of the retinas of normal and 'Rodless' Mice. Am. J. Anat., 120: 319 - 356.

Cormack, D.H. (1987): Ham's Histology ;9th ed.; J.B. Lippincott company; philadelphia;London; Mexico city; New York; St. Louis; Sao Paulo ;Sydney ;678 - 698.

Coulombre, A.J. and Coulombre J.L. (1966): Growth of lens fiber mass. Anat. Rec., 154: 355. 
Curcio, C.A. and Allen, K.A. (1990): Topography of ganglion cells in the human retina. J. Comp. Neurol., 300: 5 - 25.

Dawson, V.L. Dawson, T.M.; London, E.D.; Bredt, D.S. and Snyder, S.H. (1991): Nitric oxide mediates glutamate neurotoxicity in primary cortical cultures. Proc. Nat. Acad. Sci. USA., 88: 6368 $-6371$.

Dietrich, W.D.; Halley, M.; Alanso, O.; Globus, M.Y. and Busto, R. (1992): Intraventricular infusion of N-methyl-D-aspartate. 2. Acute neuronal consequences. Acta. Neuropathol. (Berlin) 84: 630637.

Du, Y.; Bales, K.R.; Dodel, R.C. (1997): Activation of a caspase 3related cysteine protease is required for glutamate-mediated apoptosis of cultured cerebellar granule neurons. Neurobiology, 94: 11657 - 11662.

Ehinger, B. and Dowling, J.E. (1987): Retinal neurocircuitry and transmission. In: Handbook of Chemical Neuroanatomy. Vol. V.; Bjorklund, A.; Hokfelt, T. and Swanson, L.W. (eds.) New York: Elsevier, 389- 446.

El-Idrissi A. and Trenker, E. (1999): Growth factors and taurine protect against excitotoxicity by stabilizing calcium homeostasis and energy metabolism. J. Neurosci., 19: 9459 - 9468.

Ellenhorn, M.J.; Schonwald, S.; Ordog G.; Wasserberger J. (1997): "Ellenhorn's Medical toxicology: diagnosis and treatment of human posioning". 2nd ed, Williams and Wilkins. Baltimore, Maryland, USA1071-1074.

El-Rachkawy, F.I. (1984): Late prenatal and postnatal development of the retina of albino rat. M.Sc. Thesis (Anatomy), Ain Shams University.

Ensminger, A.H.; Ensminger, M.E.; Konlande, J.E. and Robson, J.R.K. (1995): "The concise encyclopedia of foods and nutrition". CRC Press, Boca Raton, London, and Tokyo. 506 - 507.

Espinar A.; Garcia-Oliva A.; Isorna, E.M.; Quesada, A.; Prada F.A. and Guerrero, J.M. (2000): Neuroprotection by melatonin from glutamate-induced excitotoxicity during development of the cerebellum in the chick embryo. J. Pineal Res. , 28: 81 88.

Esrefoglu, M.; Gepdiremen, A. and Kurus, M. (2003): Ultrastructural clues for glutamate-induced necrosis in parietal and cerebellar neurons. Fundam. Clin. Pharmacol. Jan; 17(3): $341-7$. 
Fawcett, D.W. (1994): "Bloom and fawcett: A textbook of histology". 12th ed., Chapman and Hall. New York, London.894-917.

Fujikawa, D.G.; Shinmei, S.S.; and Cai, B. (2000): Seizure - induced neuronal necrosis: implications from programmed cell death mechanisms. Epilepsia ,41: 9 - 13.

Garthwaite, J. (1991): Glutamate, nitric oxide and cell-cell signalling in the nervous system. TINS.,14: $60-67$.

Gepdiremen, A.; Duzenli, S.; Hacimuftuoglu, A.; Sulayman, H. and Oztas, S. (2001): The effects of dandrolene alone or in combination with nimodipine in glutamate-induced neurotoxicity in cerebellar granular cell cultures of rat pups. Pharmacol. Res., 43: 241 - 244.

Goldsmith, P.C. (2000): Neuroglial responses to elevated glutamate in the medial basal hypothalamus of the infant mouse. J. Nutr., 130: $1032-1038$.

Gonzalez-Burgos, I.; Perez-Vega, M.I. and Beas-Zarate, C. (2001): Neonatal exposure to monosodium glutamate induces cell death and dendritic hypotrophy in rat prefrontocortical pyramidal neurons. Neurosci. Lett., Jan; 12; 297(2): $69-72$.

Green, D. and Kroemer, G. (1998): The central executioners of apoptosis: Caspases or mitochondria? Trends cell Biol., 8: 267 $-271$.

Hayes, A.W. (1994): Principles and methods of toxicology. $3^{\text {rd }}$ ed., Raven Press, New York. 329 - 360.

Hogan, M.J.; Alvarado, J.A. and Weddell, J.E. (1971): Histology of the human eye; Philadelphia; W.B. Saunders.

Honda, K.; Shimohama, S. and Sawada, H. (2001): Non-genomic antiapoptotic signal transduction by estrogen in cultured cortical neurons. J. Neurosci. Res., 64: 466 - 475.

Isaev, N.K.; Zorov, D.B.; Stelmashook E.V.; Uzbekov, R.E.; Kozhemyakin M.B. and Victorov, I.V. (1996): Neurotoxic glutamate treatment of cultured cerebellar granule cell induces $\mathrm{Ca} 2+$ dependent collapse of mitochondrial membrane potential and ultrastructural alterations of mitochondria. FEBS Lett., 392: 143 - 147.

Junqueira, L.C.; Carneiro, J. and Kelley, R.O. (1998): "Basic Histology" Middle East Edition of 9th ed., Librairie du Liban, Beirut, Lebanon. Appelton \& Lange, Norwalk, Connecticut, California. $456-696$. 
Kessel, R.G. (1998): "Medical histology". Oxford University Press. Inc. New York. 285-295.

Ketenmann, H. and Ransom, B.R. eds (1995): Neuroglia. Oxford.

Kiedrowski, L.; Costa, E. and Wroblewski, J.T. (1992): Glutamate receptor agonists stimulate nitric oxide synthase in primary cultures of crebellar granule cells. J. Neurochem., 58: 335 341.

Kissen, A.T. and Bloodworth, J.M.B. (1961): Ultrastructure of retinal capillaries of the rat. Exp. Eye Res., 1: $1-14$.

Kolb, H.; Linberg, K.A. and Fisher, S.K. (1992): Neurons of the human retina: a Golgi study. J. Comp. Neurol., 318: 147 - 187.

Kristian T. and Siesjo B. (1998): Calcium in ischemic cell death. Stroke, 29:705-718.

Lipton, S.A. (1994): Molecular mechanisms of trauma-induced neuronal degeneration. Curr. Opin-Neurol., 6: 588 - 596.

Liu, D.; Thangnipon, W. and Mcadoo, D.J. (1991): Excitatory amino acids rise to toxic levels upon impact injury to the rat spinal cord. Brain Res., 547: $344-348$.

Lucas, D.R. and Newhouse, J.P. (1957): The toxic effect of sodium Lglutamate on the inner layers of the retina. Arch. Ophtal., 68: $193-302$.

Lynch, D.R. and Dawson, T.M. (1994): Secondary mechanisms in neuronal trauma. Curr. Opinion Neurol., 7: 510 - 516.

Marani, E.; Rietveld, W.J. and Choufour, H. (1984): Selective degeneration of myelinated axons in the optic nerve of rats treated with monosodium-L-glutamate. IRCS Med. Sci., 12: 85 $-86$.

Massey, S.C. and Redburn, D.A. (1987): Transmitter circuits in the vertebrate retina. Prog. Neurobiol ., 28: 55 - 96.

Matyja, E. (2000): Aliminum exchanges glutamate mediated neurotoxicity in organotypic cultures of rat hippocampus. Folia. Neuropathol., 38:47-53.

Meldrum, B. and Garthwaite, J. (1990): Exitatory amino acid neurotoxicity and neurodegenerative disease. Trends Pharmacol. Sci., 11: 379 - 387.

Miller, R.F. and Slaughter, M.M. (1986): Excitatory amino acid receptors in the vertebrate retina. In: Retinal transmitters and Modulators: Models for the Brain. Morgan, W.W. (ed) Boca Raton, Florida: CRC Press:123-160. 
Mistlberger, R.E. and Antle, M.C. (1999): Neonatal monosodium glutamate alters circadian organization of feeding, food anticipatory activity and photic masking in the rat. Brain Res., Sep; 18; 842(1): 73 - 83 .

Nicholls, D.G. and Budd, S.L. (1998): Mitochondria and neuronal glutamate excitotoxicity. Biochem. Biophys, Acta, 1366: 97 112.

Nicotera, P. and Lipton, S.A. (1999): Excitotoxins in neuronal apoptosis and necrosis. J. Cereb. Blood Flow Metabol., 19: 583 - 591.

Nishizawa Y. (2001): Glutamate release and neuronal damage in ischemia. Life. Sci., 69: 369 - 381.

Ohguro, H.; Katsushima, H.; Maruyama, I.; Maeda, T.; Yanagihashi, S.; Metoki, T. and Nakazawa, M. (2002): A high dietary intake of sodium glutamate as flavoring (ajinomoto) causes gross changes in retinal morphology and function. Exp. Eye Res., 75: $307-315$.

Olney, J.W. (1969a): Glutamate-induced retinal degeneration in neonatal mice, electron microscopy of the acutely evolving lesion. J. Neuropathol. Exp. Neurol., 28: 455 - 474.

Olney, J.W. (1969b): Brain lesion, obesity and other disturbances in mice treated with monosodium glutamate. Science, 164: 719 721.

Olney, J.W.; Collins, R.C. and Sloviter, R.S. (1986): Excitotoxic mechanisms of epileptic brain damage. Adv. Neurol., 44: 857 877.

Park, C.H.; Choi, S.H.; Piao, Y.; Kim, S.; Lee, Y.J.; Kim, H.S.; Jeong, S.J.; Rah, J.C.; Seo, J.H.; L.J.H.; Chang, K.; Jung, Y.J. and Suh, Y.H. (2000): Glutamate and aspartate impair memory retention and damage hypothalamic neurons in adult mice. Toxicol. Lett., May; 19; 115(2): 117 - 125.

Pelligrini-Giampetro, D.E.; Gorter, J.A.; Bennett, M.V.L. and Zukin, R.S. (1997): The Glu R2 (Glu R-B) hypothesis: Ca2+permeable AMPA receptors in neurological disorders. Trends Neurosci., 20: 464 - 470.

Potts, A.M.; Modrell, K.W. and Kingsbury C. (1960): Permanent fractionation of the electroretinogram by sodium glutamate. Am. J. Ophth., 50:900-907.

Potts, A.M. (1965): Selective action of chemical agents on individual retinal layers. In Biochem. Of the retina, edited by Clive $\mathrm{N}$. Graymore. Academic Press, New York, 155 - 161. 
Pycock, C.J. (1985): Retinal neurotransmission. Surv. Ophthalmol., Mar-Apr; 29(5): 355 - 365.

Reichenbach, A.; Stolzenburg, J.U.; Eberhardt, W.; Chao, T.L.; Dettmer, D. and Hertz, L. (1992): What do retinal muller (glial) cells do for their neuronal small siblings? J. Chem. Neuroanato., 6: 201 - 213.

Reif-Lehrer, L.; Bergenthal, J. and Hanninen, L. (1975): Effects of monosodium glutamate on chick embryo retina in culture. Invest-Ophthalmol., Feb; 14(2): $114-124$.

Rigdon, G.C.; Boyes, W.K. and Dyer, R.S. (1989): Effect of perinatal monosodium glutamate administration on visual evoked potentials of juvenile and adult rats. Neurotoxicol Teratol., Mar-Apr; 11(2): 121 - 128.

Sapolsky, R.M. (2001): Cellular defenses against excitotoxic insults. J. Neurochem., 76: $1601-1611$.

Segal, J.A. and Skolnick, P. (2000): Spermine-induced toxicity in cerebellar granule neurons is independent of its actions at NMDA receptors. J. Neurochem., 74: 60 - 69.

Seress, L.; Lazar, G.; Kosaras, B. and Robertson, R.T. (1984): Regional effect of monosodium-L-glutamate on the superficial layers of superior colliculus in rat. Cell tissue Res., 235(2): 453 - 457.

Siliprandi, R.; Canella, R.; Carmignoto, G; Schiavo, N.; Zanellato, A.; Zanoni, R. and Vantini, G. (1992): N-methyl-D-aspartate induced neurotoxicity in the adult rat retina, Vis. Neurosci., 8: $567-573$.

Sisk, D.R. and Kuwabara, T. (1985): Histologic changes in the inner retina of albino rats following intravitreal injection of monosodium L-glutamate. Graefes Arch. Clin. Exp. Ophthalmol. ,223(5): 250 - 258.

Snell, R.S. (1984): Clinical and functional histology for medical students. Little, Brown and Company, Boston, Toronto.

Snyder, S.H. and Bredt, D.S. (1991): Nitric oxide as a neuronal messenger. TIPS., 12: $125-127$.

Spoerri, P.E. and Glees, P. (1977): Subsurface cisterns in the Cynomolgus retina. Cell Tiss. Res., 182: 33 - 38.

Stern, J.R.; Eggleston, L.V.; Hems, R. and Krebs, H.A. (1949): Accumulation of glutamic acid in isolated brain tissue, Biochem. J. 44 : 410 - 418.

Ts'O, M.O.M. and Friedman, E. (1967): The retinal pigment epithelium. 1-Comparative histology. Arch. Ophthalmol. 18: 641 - 649. 
Van Westerlaak, M.G.; Joosten, E.A.; Grignou, A.A.; Cools A.R. and Bar, P.R. (2001): Chronic mitochondrial inhibition induces glutamate-mediated corticomotor neuron death in an organotypic culture model. Exp. Neurol.,167:393-400.

Villegas, G.M. (1964): Ultrastructure of the human retina. J. Anat. London, 98(4): 501 - 513.

Walker, R. and Lupien, J.R. (2000): The safety evaluation of monosodium glutamate. J. Nutr. Apr; 130 (4S Suppl): 1049 S $1052 \mathrm{~S}$.

Walls, G.L. (1942): The vertebrate eye and its adaptive radiation. Cranbrook Institute of Science Bul., No. 19, Cranbrook Press. Bloom field Hills, Haffner, New York, 453 - 508.

Warwick, $R$. (1976): Wolff's anatomy of the eye and orbit. 7th ed., W.B. Saunders Co., Philadelphia, Toronto, 99 - 160. And $463-480$.

Watzke, R.C.; Soldevilla, J.D. and Trune, D.R. (1993): Morphometric analysis of human retinal pigment epithelium correlation with age and location. Curr. Eye Res., 12: 133 - 142.

Williams, P. and Warwick, R. (1980): Gray's anatomy; $36^{\text {th }}$ ed.; Churchill Livingstone; Edinburgh; London; Melbourne and New York.

Williams, P.; Bannister, L.H.; Berry, M.; Collins, P.; Dyson, M.; Bussek, J.E. and Ferguson, M.W.J. (1995): Gray's anatomy; 38th ed.; Churchill livingstone; Edinburgh;London ;Melbourne and New York.

Wong, R.O.L. and Hugues, A. (1987): The morphology, number and distribution of a large population of confirmed displaced amacrine cells in the adult cat retina. J. Comp, Neurol., 255: $159-177$.

Wood, A.M. and Bristow, D.R. (1998): N-methyl-D-aspartate receptor desensitisation is neuroprotective by inhibiting glutamate induced apoptotic-like death. J. Neurochem., 70: $677-687$.

Wyllie, A.H. and Duvall, E. (1992): "Cell injury and death, in: McGee, J.O.D."; In Oxford textbook of pathology, Isaacson, P.G.; Wright N.A. (Eds.), Oxford University Press, Oxford, New York. $141-150$.

Reynolds, E. G. (1963): The use of lead citrate at high $\mathrm{pH}$ as an electron opaque stain in electron microscopy. J. Cell Biol. (17): 208:212. 